\title{
ARABIC LITERARY ELEMENTS IN THE STRUCTURE OF THE LIBRO DE BUEN AMOR (II)*
}

\author{
ELEMENTOS DE LA LITERATURA ÁRABE EN LA \\ ESTRUCTURA DEL LIBRO DE BUEN AMOR (II)
}

\author{
JAMEs T. MonRoe \\ University of California, Berkeley \\ In memory of Charlotte Stern, \\ a friend of many years standing, \\ and a deeply respected colleague.
}

This article examines several aspects of Arab-Islamic culture, about which Juan Ruiz, Archpriest of Hita, and putative author of the Libro de buen amor, betrays evidence of some knowledge. It goes on to suggest that, while the $L B A$ 's literary materials are largely of Western origin, its structure is indebted to a unique combination of certain Oriental literary genres, thereby making it a culturally hybrid work. The article further suggests that the $L B A$ may be read according to three levels of meaning, in accordance with the Averroistic approach to, and conception of, truth, of which the highest, or philosophical level, involves a veiled critique of the doctrine of ecclesiastical celibacy, adopted by the Western Church only a century before the Archpriest composed his work.

Key words: Averroes; Frametale; Hybridization; Ibn al-Muqaffa'; Ibn Quzmān; Kalīla wa-Dimna; Libro de buen amor; Maqāma; Mudéjar; Mu'tazila; Juan Ruiz, Archpriest of Hita; Zajal.
En este artículo se examinan algunos aspectos de la cultura arabigoislámica de los cuales Juan Ruiz, Arcipreste de Hita, presunto autor del Libro de buen amor, demuestra poseer cierto conocimiento. De resultas se sugiere que, mientras los materiales literarios constituyentes del Libro son de raigambre occidental, su estructura se debe a una combinación de ciertos géneros literarios orientales, de lo cual el Libro resultaría ser una obra culturalmente híbrida. Además, se sugiere que el $\mathrm{Li}$ bro debe interpretarse según tres niveles de significado, de acuerdo con la metodología desarrollada por Averroes para captar la verdad, y que, de esos tres niveles, el más elevado, a saber, el filosófico, nos conduce a una crítica velada de la doctrina del celibato eclesiástico, adoptada por la iglesia occidental sólo un siglo antes de la época en que el Arcipreste escribiera su obra.

Palabras clave: Averroes; relato-marco; hibridación; Ibn al-Muqaffa'; Ibn Quzmān; Kalīla wa-Dimna; Libro de buen amor; Maqāma; Mudéjar; Mu'tazila; Juan Ruiz, Arcipreste de Hita; Zấal.

* This article is published in two parts, the first one has been published in the issue of January-June 2011. 


\section{Arabic into Latin: Islamic Theology, Arabic Philosophy, and the "Libro de buen amor"}

In his introduction to the Book of Kalīla wa-Dimna, 'Abdullāh b. al-Muqaffa' keeps insisting that the work he is presenting for the first time to an Arabic-speaking audience has both an exoteric and an esoteric dimension, and that it should not be read for its surface meaning alone:

It is imperative that the reader of Kalilah and Dimnah should grasp the meaning beyond the text [...] frustration awaits anyone who reads this book of fables without comprehending both the apparent and the implicit ideas within [...] the book of fables, Kalilah and Dimnah, is not written for entertainment only [...] the reader should therefore spend time on understanding every fable and every word in the book [...] [he] should therefore spend careful and tireless time on understanding it [...] similarly, people who miss the point of this book and do not comprehend its deeper meanings, but are satisfied with the superficial, are like the ignorant fisherman [...] there are insights intended for the royalty, the gentry, and common folk as well [...] and there is wisdom here ultimately and exclusively meant only for philosophers. ${ }^{76}$

In Arabic literature, such warning instructions to the reader became standard fare in a number of works of prose fiction written with a didactic purpose in mind. Thus, al-Harīīi of Bașra (445/1054-515/1122), the author of a major collection of maqamas specifies:

I know that although he who is intelligent and liberal will connive at me, and he who is friendly and partial may defend me,-I can hardly escape from the simpleton who is ignorant, or the spiteful man who feigns ignorance;-Who will detract from me on account of this composition, and will give out that it is among the things forbidden of the law.-But yet, whoever scans matters with the eye of intelligence, and makes good his insight into principles-Will rank these Assemblies in the order of useful writings, and class them with the fables that relate to brutes and lifeless objects.-Now none was ever heard of whose hearing shrank from such tales, or who held as sinful those who related them at ordinary times.Moreover, since deeds depend on intentions, and in these lies the effectiveness of religious obligations,-What fault is there in one who composes stories for instruction not for display, and whose purpose in them is the education and not the fablings?-Nay, is he not in the position of one who assents to doctrine, and "guides to the right path?" 77

76 Jallad, The Fables of Kalilah and Dimnah, 29-30, 34-36.

${ }^{77}$ Chenery, Th. (transl.), The Assemblies of Al-Harìri, London, 1867, 107.

Al-Qanțara XXXII 2, julio-diciembre 2011, pp. 307-332 ISSN 0211-3589 
Likewise, in Andalus itself, al-Saraqusțī (d. 538/1143), who was al-Ḥarīrì's greatest Arabic imitator, states:

We implore whoever considers and takes note of these words of ours, and strives and aspires to understand them with a critical appraisal, to be judicious and apply allegorical interpretation $\left(t a^{\prime} w \bar{l} l\right)$ in his examination of them, to make it his practice and conclusion to judge them favorably ... ${ }^{78}$

Similarly, in Hebrew, the Hispano-Jewish author Judah al-Harīzī (ca. 1170-1235) in his Tahkemoni, a collection of maqämas written in imitation of al-Harīīi, has much the same to say in his prologue:

And in [this work] I have prepared for every one his nook and his book, every one to his service and to his burden: He who fears the word of the Lord will find in it reproofs and prayers and the fear of the Lord. And he who regards not the word of the Lord will find in it the delights of the world and its good things and they shall flow unto the goodness of the Lord. And every fool and brutish man whether he be aged or young will learn from its wisdom, to give prudence to the simple, to the young man knowledge and discretion. And every wisehearted person, if he opens his eyes to it, the wise man will hear and will increase learning. And whoever seeks to learn good manners, through it will prosper whithersoever he turns, and the man of understanding will attain unto wise counsels. And whoever composes poems and has hewn out broken cisterns whose waters are bitter, through this book he will open his eyes. And the Lord will show him a tree, and he will cast it into the waters, and the waters will become sweet.

And every one whose soul hungers for pleasant bread and the delights of songs of friendship and the sweet things of parables and riddles will find them in this book ten-fold abundant - jar and cruse in which the blessing of the Lord blossoms. And if he takes from them wisdom and instruction, the jar of meal will not be spent, neither will the cruse of oil fail! For its table is prepared for all who come, and its house is forever blessed; its food may be eaten by anyone and all who are hungry may come and eat. ${ }^{79}$

Thus, Juan Ruiz is following a venerable tradition, when he writes, in his introduction to the $L B A$ :

I composed this new book in which some of the techniques, skills and deceiving subtleties of the foolish love of this world are described, which some folk use to sin. If any man or woman of good understanding reads or hears them and wishes to be saved, he or she must make a choice and act upon it [...] but those of little understanding shall not be lost because when they read about the evil

${ }^{78}$ Monroe, al-Maqāmāt al-Luzūmīyah, 502.

79 Al-Ḥarīzì, J., The Tahkemoni, V.E. Reichert (transl.), Jerusalem, 1965, 1, 37-38.

Al-Qanțara XXXII 2, julio-diciembre 2011, pp. 307-332 ISSN 0211-3589 
they do, or intend to do [...], they will arouse their memory and will not despise reputation, for it is wicked to do so [...] and they will want to love themselves more than they love $\sin [\ldots]$ and they will cast aside and abhor the evil ways and wiles of foolish love, through which the soul is lost [...] however, because it is human to sin, if some people want to indulge in the excesses of worldly love, which I do not advise, they will find various ways to do so described here [...] I beg and advise whoever may hear or read this to cultivate the three attributes of the soul: firstly, to be able to understand and judge my intention correctly, as well as the reason for writing the book, and its meaning, and not be misled by the deceiving sound of the words. The rules say that the words are subservient to [the] purpose and not the purpose to the words. And God knows that my purpose was not to write it to suggest ways of sinning, nor to speak evil, but to guide everyone to the clear recollection of how to do good and set a good example in their habits and penances on the road to salvation. ${ }^{80}$

As we have seen, Ibn al-Muqaffa' was not a Muslim, but a Manichaean. ${ }^{81}$ Nevertheless, during his formative years in Bașra, he was deeply influenced by the Islamic theological school known as the Mu'tazila. ${ }^{82}$ Similarly, Badī' al-Zamān al-Hamadhān̄ (358/968$398 / 1008$ ), the inventor of the maqāma genre, at the time he wrote his collection, was a Shí ${ }^{-}$ite, ${ }^{83}$ the latter being a confession of Islam that incorporated into its system the theological principles of the $\mathrm{Mu}$ 'tazila, according to which, sacred texts such as the Qur'ān needed to be interpreted allegorically rather than understood literally, as previously summarized. Ultimately, all the authors from whose prologues we have quoted above, including Juan Ruiz, are distinguishing, in one way or another, between the intelligent reader, who is capable of penetrating beyond the surface of the text in order to get at its true, esoteric sense, and the ignorant reader, who is unable to do so, and is, therefore, doomed to derive a false message from the text.

This distinction between the intelligent and the ignorant reader became central to the thought of the great Andalusi philosopher Ibn Rushd (Averroes, 520/1126-595/1198), ${ }^{84}$ According to Ibn Rushd,

${ }^{80}$ LBA, ed. Drayson, 11 (emphasis mine).

${ }^{81}$ Guidi, La lotta tra l'islam; Gabrieli "Ibn al-Muqaffa".

82 Jallad, The Fables of Kalilah and Dimnah, 14-17; Brockelmann, "Kalīla waDimna", $E I^{2}$.

${ }^{83}$ Monroe, J.T., The Art of Bad̄̄‘ az-Zamān al-Hamadhānī as Picaresque Narrative, Beiruth, 1983.

${ }^{84}$ Curiously, Ibn Quzmān devoted his entire Zajal 106 to the praise of Ibn Rushd. It must have been composed when that philosopher was still very young.

Al-Qantara XXXII 2, julio-diciembre 2011, pp. 307-332 ISSN 0211-3589 
there is only one truth, but that truth is perceived and understood differently by three different mindsets, namely that of the rational philosophers, the dialectical theologians, and the literal masses. Ibn Rushd maintained that the philosophical understanding of truth, based on reason alone, was superior to the dialectical understanding of truth, based on revealed texts, that is, on faith. Finally, both these forms of understanding were superior to the literal or rhetorical understanding of truth prevalent among the ignorant masses. This was so because words, being ambivalent, needed to be interpreted correctly. ${ }^{85}$

Whereas Ibn Rushd argued that truth was one and indivisible, but that the understanding of that truth differed according to the intellectual level of each individual, his medieval European followers, the so-called Latin Averroists, modified his doctrines in order to maintain that there were two truths, that of reason and that of faith, both of which were equally valid, and between which there was an absolute incompatibility. ${ }^{86}$ In the $L B A$, ss. 123 to 165 , there is a long passage in which Juan Ruiz points out the great importance of astrology in determining the course of human lives, a doctrine dear to the Latin Averroists. Surprisingly, however, the passage ends with the conclusion that, since God created the stars that rule over human life, He can also modify or suppress their influence. Thus, according to the Archpriest, the world is not ruled by blind Fate, but by an intelligent Providence. This passage is a direct refutation of some of the basic, fatalist principles espoused by the Latin Averroists. Throughout the book, furthermore, Juan Ruiz appears to be relying upon true Averroism in his arguments. For example, in s. 105b, he cites Solomon's dictum que las cosas del mundo todas son vanidat ('all worldly

${ }^{85}$ On this point, see Gautier, L. (ed. and transl.), Ibn Rochd (Averroès): Traité décisif (Façl el-maqâl) sur l'accord de la religion et de la philosophie, suivi de L'appendice (Dhamima), Algiers, 1948; Hourani, G.F. (ed.), Ibn Rushd (Averroes): Kitāb Faṣl alMaqāl, with its Appendix (Damìma) and an Extract from Kitāb al-Kashf 'an Manāhij al-Adilla, Leiden, 1959.

${ }^{86}$ The difference between true Averroism on the one hand, and the doctrines of the Latin Averroists on the other, has been known since Ernest Renan explained it in the midnineteenth century (Renan, E., Averroès et l'averroisme: essai historique, Paris, 1852). As M. Asín Palacios further explained, true Averroism came to be a basic component of the doctrines of Saint Thomas Aquinas (1225-1274), whose thought it deeply influenced. Thus, true Averroism would have been available to Juan Ruiz, even if only through Latin sources. See Asín Palacios, M., Huellas del islam: Santo Tomás de Aquino, Turmeda, Pascal, San Juan de la Cruz, Madrid, 1941. 
things are vanity'). Three stanzas below, he proceeds to give up on a lady he had previously hoped to seduce, on the grounds that she is unavailable, thereby violating the very courtly love code he himself professes to follow, while at the same time betraying that he is an unreliable narrator. He eventually stops licking the wounds he has incurred as a result of being rejected by the lady, and decides that he will refrain from speaking badly of her ca en muger loçana, fermosa e cortes, / todo bien del mundo e todo plazer es ('because in a lively, beautiful and courteous woman / lies all the pleasure and goodness in the world' [s. 108cd]). Here, Ibn Rushd's educated reader would immediately be able to complete the implied syllogism that the author has left unfinished, as follows: (1) All worldly things are vanity. (2) Woman holds all the goodness in this world. (3) Ergo, the (frivolous) pursuit of women is vanity. This conclusion is justified throughout the rest of the $L B A$ by the misadventures of our hapless Archpriest who, aside from the hideous mountain women who rape him despite his protestations, only succeeds in "winning" (whatever that may imply) two women, both of whom are nuns. One of the nuns dies only a few days after succumbing to the go-between's ministrations of atincar, raynela, and mohalinar (s. 943), and the other, named Doña Garoça (Colloquial Arabic 'arūsa 'bride'; in this context, a "bride of Christ"), (ss. 1321-1507), dies within two months of being "won", thereby confirming the saying of Solomon to the effect that "all worldly things are vanity". The Archpriest as literary persona, in his frenzied pursuit of amorous liaisons rather than true love (since he is a man of the cloth, he cannot marry) never realizes the vanity of his activities, whereas the Archpriest as author is teaching the intelligent reader by negative example, in much the same way that the trickery in the maqāma genre, and the buffoonery in the Quzmānī zajal teach the intelligent reader (Ibn Rushd's dialectical mind) by negative example.

So far we have two possible interpretations of the $L B A$ : (1) A rhetorical interpretation, namely that of the ignorant masses who heedlessly follow the words of the Archpriest against his clear advice: "If some people want to indulge in the excesses of worldly love (loco amor), which I do not advise, they will find various ways to do so described here". ${ }^{87}$ Since the examples of worldly love provided are

${ }^{87} L B A$, ed. Drayson, 11.

Al-Qanțara XXXII 2, julio-diciembre 2011, pp. 307-332 ISSN 0211-3589 
all about lust rather than love, and since all of them are attempts at seduction that end in failure, this interpretation is clearly an inferior one. (2) A dialectical interpretation, based upon faith, namely that, in attempting to violate the Church ruling concerning ecclesiastical celibacy, the Archpriest is a prime example of the sinful cleric, while both his behavior and his justification for that behavior should be rejected by the reader. According to this interpretation, the text teaches us by negative example.

There is, however, a possible, third, and philosophical interpretation based upon reason. At this stage in our reading, we may note that the only person the Archpriest is (perhaps?) successful in seducing is one of two nuns, ${ }^{88}$ that is to say, two persons who are prohibited from engaging in sexual intercourse by the very same rules of ecclesiastical celibacy as himself. It is even the case that, when the Archpriest attempts to seduce the Moorish woman, she rejects him, thereby showing that even a non-Christian woman can be more virtuous that a Christian priest. This leads one to wonder whether the $L B A$ is not, in its ultimate agenda, a veiled critique of the doctrine of ecclesiastical celibacy itself. ${ }^{89}$

In this respect, there is a curious passage in the work, the ultimate implications of which have not, to the best of my knowledge, been yet fully grasped. In the episode in which the Archpriest attempts to seduce Cruz, the female baker, but makes the mistake of sending to her, as his go-between, the impudent young rascal Ferrand García, who seduces the lady for himself ( $L B A$ ss. 115-122), the Archpriest comments: "tome senda por carrera / commo [haz el] andaluz" ("I mistook a pathway for a highway / as does the Andalusian'). ${ }^{90}$ In his

${ }^{88}$ In this case the love seems to be of the "pure" variety. Note that the previous nun, won by the Archpriest, dies of an overdose of Arabic drugs administered by the procuress.

89 This view was convincingly defended by Márquez Villanueva, F., "Juan Ruiz, Arcipreste de Hita, y el 'Libro de buen amor"', Actas del Congreso Internacional del Centro para la Edición de los Clásicos Españoles, F. Toro Ceballos and B. Morros Mestres (eds.), Alcalá La Real, 2004, 15-35. In what follows, I shall argue in its favour from a slightly different persepective. Let us keep in mind that the struggle to impose ecclesiastical celibacy on Christianity went on for a thousand years, and finally succeeded, if only in the Western Church, during the thirteenth century. Such an imposition would, therefore, have been a relatively recent one to the world of Juan Ruiz. See Abbott, E., A History of Celibacy, Cambridge, Mass., 2000, 107-114.

${ }^{90} L B A$, s. $116 \mathrm{~cd}$.

Al-Qanțara XXXII 2, julio-diciembre 2011, pp. 307-332 ISSN 0211-3589 
edition of the $L B A$, Joan Corominas alludes to a statement by Américo Castro according to which Andalusians are typically stereotyped as being daydreamers. ${ }^{91}$ While this may be a modern ethnic slur aimed by Northern Spaniards at their Southern countrymen, it is not necessarily valid for the medieval period. Instead, in this context, it is more likely that the term andaluz is being used in a fourteenthcentury meaning as 'Andalusî', with reference to the Muslims of the Kingdom of Granada. ${ }^{92}$ There is, however, more to the matter, for by stating that he "mistook a pathway for a highway / like the Andalusī Moor", or "like the entirety of al-Andalus", the author is implying, by way of contrast, that the religion of Christianity is a "highway", whereas that of Islam is a mere "pathway" to salvation or, put differently, that Christianity is a more reliable road to heaven than is Islam. ${ }^{93}$

${ }^{91}$ Corominas (ed.), Libro de buen amor, 102, n. 116d.

92 An alternate interpretation would be to emend the text to commo [haz al]andaluz ('as al-Andalus does'). This would not, however, change my argument, below.

${ }^{93}$ For the medieval Spanish usage of the word carrera with the specific meaning of a religion, see Alfonso X, el Sabio, Primera crónica general de España, R. Menéndez Pidal (ed.), Madrid, 1, 74a, where the learned King rails against Muslims on the grounds that "non se quieren llegar nin acoger a la carrera de la uerdadera fe nin auer en si la ley de Dios nin el su ensennamiento" ("they do not wish to approach or adopt the highway of the true faith, nor to take up either the religion of God or its teaching'. Similarly, Martín Pérez, in his Libro de las confesiones $(78,11.4-5)$ refers to the carrera del infierno ('highway to Hell') which he contrasts with the carrera de vida ('highway to [everlasting] life')" in the context of considering whether it is lawful for Christians to abduct the children of Muslims, in order to bring up those children as Christians. Pérez rules that it is, indeed, lawful so to do, if the intention is to save those children's souls. The word carrera, deriving from a Vulgar Latin form * carraira, and of which there are cognates in all the Romance languages, originally designated a road used for the transit of chariots and four-wheeled baggage-wagons (carri). In the Primera crónica general de España, however, it has clearly acquired a religious connotation lacking in the other Romance languages, but remarkably similar to that of the Arabic word shari' 'a, the meaning of which ranges from 'a watering-place' and 'a way to water', to 'the religious law of God' (Lane, Arabic-English Lexicon, 4, 1533, col. c [emphasis mine]). This leads one to suspect that the medieval Spanish word carrera, as used by Alfonso X and Martín Pérez, may be a possible loan translation of the Arabic concept expressed by the term $\operatorname{sharí}^{\prime} a$. It should also be noted that, on the level of language, loan translations from Arabic into Spanish are a further example of hybridization, in which the form of the word is Latin/Romance, whereas its meaning is Arabic. In this sense, they represent linguistic "micro-mudejarisms". Another such loan translation, as yet unidentified, to the best of my knowledge, may possibly be the term mal amigo ( $L B A, \mathrm{~S}, \mathrm{~T}, \mathrm{~s} .1465 \mathrm{~b})$ applied to Satan, and which seems to correspond to the term șâhi saw ('evil friend', or 'friend of evil' in which the Colloquial Arabic form șâhī represents the Classical șăhib ['friend'], and the Colloquial form saw stands for the Classical sū' ['evil']), found in Ibn Quzmān's Zajal 90:6a, where it also refers to Satan.

Al-Qanțara XXXII 2, julio-diciembre 2011, pp. 307-332 ISSN 0211-3589 
This idea, in turn, offers a far more tolerant view of Islam than does the official medieval Christian view of that religion, namely that the Prophet Muhammad had originally been a Christian, and that what he had founded was little more than a heresy, rather than a fullfledged new religion. That is to say, if Islam was merely a Christian heresy, rather than an independent religion in its own right, then the Church was justified in taking inquisitorial action against Muslims. This portrayal of the Prophet as a heretical Christian seems to have originated among the Mozarabs of al-Andalus in the ninth century, ${ }^{94}$ it was incorporated into Alfonso X's Primera crónica general de España in the thirteenth, ${ }^{95}$ and eventually made its way into Dante's Inferno, where that poet places Muhammad in the circle of the schismatics. ${ }^{96}$ In contrast, Islam has always recognized that Judaism and

${ }^{94}$ In a letter directed by Iohannes of Seville to Alvarus of Córdoba, Muslims are referred to as "Mammetis heretici" ('heretics of Muhammad'). See Gil, Iohannes [Juan Gil] (ed.), Corpus Scriptorum Muzarabicorum, Madrid, 1973, 1, 200, parag. 8, 1.1. The Prophet is described as "Ortus est Mammet hereticus Arabum pseudoprophetarum sigillus, Antixri precessor, tempore imperatoris Eraclii, anno septimo" ('Muhammad, the heretic of the Arabs, the seal of the pseudoprophets, the precursor of the Antichrist, was born in the seventh year of the reign of the Emperor Heraclius'), (ibid., p. cit., parag. 9, 11. 1-2). In the preface to his Memoriale Sanctorum, Eulogius speaks of the "sectae huius auctorem Mahomad fore praedixit" ("the sect Muhammad, its founder, later proclaimed'), (ibid., 2, 367, parag. 2, 11. 7-8), while in his Apologeticus Martyrum he adds: "Exortus est namque Mahomat haeresiarches tempore Heracli imperatoris" ('For indeed, Muhammad the arch-heretic appeared in the time of the Emperor Heraclius'), ibid., 483, parag. 16, 1.1 .

95 Ed. Menéndez Pidal, 1, 261-275, sections 466-467, 469, 471-472, 475, 478, 483, 486-489, 493-494. This account of the life of Muhammad states that the Prophet studied with a Jewish astrologer and a Christian heretic, from whom he borrowed much that he incorporated into his sect (rather than religion-the former being the term consistently used to denote Islam, which is thereby demoted to the category of a mere heresy of Christianity). Nevertheless, the learned King Alfonso must have had second thoughts on the matter, for in his Siete partidas, he makes a clear distinction between Jews and Moors (whom he sees as members of two independent religions), on the one hand, and heretics on the other. Within his realms, Jews and Moors were to be treated with tolerance, while any attempts to convert them to Christianity were to be made through persuasion alone, and conversion was to be purely voluntary, whereas heretics were to be burned at the stake. See Alfonso X el Sabio, Las siete partidas (el libro del fuero de las leyes), J. Sánchez-Arcilla Bernal (ed.), Madrid, 2004, Partida Séptima, "De los judíos", 960-962, "De los moros", 963-965, "De los herejes", 966-967.

96 Dante Alighieri, La Divina Commedia, C.H. Grandgent (ed.), Boston, 1933, Inferno, Canto xxviii, vv. 22-42, 250-251. The scene is set in the Eighth Circle, Ninth Pouch of Hell where the sowers of scandal and schism, perpetually circling, are wounded and - after each healing - wounded again by a demon with a sword. Grandgent comments: "Some of Dante's contemporaries believed Mahomet to have been originally 
Christianity are true and valid religions based upon legitimately recognized divine revelations made to God's chosen prophets. While Islam does view itself as the product of a final, perfect revelation ${ }^{97}$ and, therefore, as superior to all previous revelations, it also considers that these earlier revelations, though imperfect with respect to Islam, are by no means entirely invalid. In other words, from the Islamic perspective, Judaism and Christianity are "pathways", whereas Islam is a "highway". Our author, who, as we have suggested above, was possibly brought up as a Muslim in his early childhood, is now reversing matters and implying that Islam is not a mere heretical offshoot of Christianity and, therefore, to be dismissed entirely, but rather, that it is a legitimate religion in its own right. $\mathrm{He}$ is also relying on a basic Muslim principle, according to which celibacy is specifically forbidden in Islam, in order to raise questions in the reader's mind about the Christian rule of ecclesiastical celibacy. ${ }^{98}$ If the above reading is acceptable, we then have a work that allows for three possible interpretations, according to the precepts of Ibn Rushd, of which the third, in its criticism of a major Church doctrine, is patently subversive. Let us now turn to examine how the above theological and philosophical principles are instrumental in shaping the $L B A$ 's literary structure, and vice-versa.

not only a Christian, but a cardinal and an aspirant to the papacy. The poet, then, was justified in regarding him and his son-in-law Ali as the leaders of a great schism in the Christian Church" (Dante, La Divina Commedia, 247). As the founder of the Shi' 'ite sect of Islam, 'Alī, whom Dante places along with Muhammad in the Eighth Circle, would have been seen by the poet as having produced a second schism within the first.

97 This is based on the interpretation of two key Qur'ānic passages: (1) "Today I have perfected your religion for you, and I have completed My blessings upon you" (5:3), interpreted to mean that God's religion is now perfect and, therefore, needs no further revelations such as came before it, and (2) "Muhammad is not the father of any one of your men, but the Messenger of God, and the Seal of the Prophets" (33:40), interpreted to mean that there will be no further Prophets after Muhammad. The earlier revelations of Judaism and Christianity are, according to these two interpretations, recognized as valid and legitimate, even if they are only temporary and imperfect.

${ }_{98}$ On the history of the Islamic principle according to which "there is no monasticism in Islam", used to encourage marriage and to reject categorically the Christian institution of ecclesiastical celibacy, see Wensinck, A.J., "Rahbāniyya", EI 2, 8, 396b-397a. 


\section{The Structure of the "Libro de buen amor" - An Onion-Poem?}

Aside from a few fragmentary sources, including one from a lost Portuguese translation, the $L B A$ has come down to us in three major MSS. ${ }^{99}$ Each of these three MSS provides extensive passages of the total extant corpus, while at the same time omitting others. As a result, modern editors have pieced together a version that does not exist in any single source. The passages are, however, long enough (involving considerable overlapping) to allow the editor to gain some sense of their ordering. ${ }^{100}$ This has also led to several theories of authorship, ranging from one, according to which the work's different parts were composed by different authors, to another, according to which one author composed the entire work over an extended period of time, adding to it as he went along. According to the latter theory, the different MS versions would reflect different stages in the author's composition of the text. In turn, the overall nature of the textual evidence has led to an understandable, if regrettably atomistic tendency in scholarly studies of the $L B A$, according to which the work's parts are examined with great erudition, detail, and attention to sources, whereas its overall structure and organic unity are all too often overlooked. In his critical edition of the $L B A$, for example, Joan Corominas subscribes to the views of $\mathrm{H}$. Hatzfeld to the effect that the work is "a rhymed causerie [...] far from any concern for composition, a medieval intentional patchwork". ${ }^{101}$

On the other hand, modern editors, in reconstructing the $L B A$ from its disparate sources, have shown remarkable agreement in the results of their labors, insofar as the ordering of the text is concerned. In turn, this is encouraging, insofar as it indicates that, even if this great masterpiece of Spanish literature has not survived in its entirety, or even if it has been added to by later hands, it may still be possible to outline the main features of its structure and, hence, to probe more deeply into its meaning. It is in this spirit that the following overall structure is proposed.

99 All of these texts are included in the edition by Criado de Val and Naylor.

${ }^{100}$ See the table of verse-correspondences between the three MSS in Corominas (ed.), Libro de buen amor, 635, as well as in the edition by Criado de Val and Naylor.

${ }^{101}$ Corominas (ed.), Libro de buen amor, 23, n. 14.

Al-Qantara XXXII 2, julio-diciembre 2011, pp. 307-332 ISSN 0211-3589 
Beginning with s. 20 and continuing until s. 43, we have two songs devoted to the Joys of the Virgin Mary, the first of which is zajal-like in structure. These correspond to two other songs, also devoted to the Joys of the Virgin Mary, but placed toward the end of the work, between ss. 1635 and 1649 . I shall designate these two thematic units respectively, as A and A'.

From ss. 44 to 63 we find the debate between the Greeks and Romans, in which each of two characters, one a Roman "ruffian" and the other a Greek "philosopher" (in reality, a theologian), who are Ibn Rushd's rhetorical and dialectical readers respectively, misinterprets the gestures made by the other, in a debate held in sign language. The author thereby warns the reader not to misinterpret the book, which has deeper, esoteric levels of meaning. This theme is again taken up in ss. 64 to 70 , containing a more explicit warning to the reader, to the effect that the $L B A$ has both an exoteric and an esoteric meaning, of which the latter can only be grasped by the critically discerning. This passage corresponds precisely with the one found toward the end of the work, between ss. 1626 and 1634, in which the same warning is reiterated. Let us designate the first of these passages as B, and the second as B' respectively. Furthermore, it is instructive to note that both the rhetorically inclined "ruffian", and the dialectically inclined "philosopher" manage to get things wrong, thereby leaving it to the implied and rationally inclined "omniscient" reader to get them right.

From ss. 115 to 122 , we have the misadventure with Ferrand García: The Archpriest has not yet acquired the expertise in seduction that he will gain from the teachings of Don Amor and Doña Venus, hence he makes the mistake of hiring a young man, instead of an old woman, as his go-between. The predictable consequence of this mistake is that Ferrand García, who is cleverer than his employer, betrays the latter by successfully courting and winning Cruz, the female baker, for himself. This passage corresponds to that contained between ss. 1618 and 1625, in which the Archpriest, whose elderly go-between, Trotaconventos, has recently died, sends his servant-boy Don Furón, who is more foolish than himself, to court a certain lady on his behalf. The Archpriest composes a love song and gives it to the boy for the latter to present to the lady. The witless youth proceeds to sing it out loud and in public, as he approaches the lady's house, thereby making the Archpriest's intentions known to the whole town. 
Fearing for the loss of her reputation, the lady refuses to receive the boy, and slams her door in his face. We have here, two young male procurers, of whom one is clever enough to outwit his master, whereas the other is too foolish to plead the latter's cause successfully. Let us designate these two corresponding motifs as $\mathrm{C}$ and $\mathrm{C}$ ' respectively. The first is introduced before the Archpriest obtains the services of Trotaconventos, and the second, after she has died and can, therefore, no longer be of service to him. The fact that, in the second episode, the Archpriest again chooses to hire a youth rather than an old woman, contrary to Don Amor's earlier instructions, further indicates that he has learned nothing from his experiences, and is, in fact, a consummate fool.

There are further, implied sexual images linking these two sections of the poem: In section C, Ferrand García (whose name is connected to the use of the word garcia as an archaic name for 'fox'), is also described as a conejero (literally 'rabbit-catcher'), i. e. a dog or ferret, while conejo ('rabbit') also meant 'vulva'. ${ }^{102}$ Therefore, he is a cunning, "foxy" seducer of women. In contrast, in section C', Don Furón's name literally means Sir Ferret, that is to say, he is an animal used in the hunting of rabbits, who does so by penetrating their burrows (with all that this implies on the level of obscenity) but who, in the process, uses brute force rather than cunning. Thus Ferrand García, the fox, gets the rabbit by use of stealth, where Don Furón, the ferret, fails in his attempts, for lack of cunning.

The passage between ss. 181 and 652 contains a long debate between the Archpriest and Don Amor, in which the former strongly resists the feminine charms the latter temptingly describes to him. The passage is, therefore, an attempted seduction of the Archpriest, which we shall designate as section D. During the course of the debate, each of the two parties tells stories intended to win his opponent over to his own side. In rejecting the devious arguments of Don Amor, the Archpriest repeatedly tells him to get out of his house (the entire rejection scene spans ss. 372-422, while the Archpriest specifically tells the god to go away in ss. 389d, 406d, 422d). This motif, we will designate as section $\mathrm{E}$. In his vain attempts to overcome the Archpriest's resistance to his arguments, Don Amor paints, for the latter's benefit, a verbal portrait of the ideal lady the Arch-

${ }^{102}$ Márquez Villanueva, "Spanish Cazurro Poetry", 95-96.

Al-Qanțara XXXII 2, julio-diciembre 2011, pp. 307-332 ISSN 0211-3589 


\section{priest should strive to seduce (F) in ss. 431-435, and the god's portrait of her is one of a small-headed, blonde lady. ${ }^{103}$ Seeing that he is}

103 In several of his zajals, Ibn Quzmān consistently describes himself as being blond and blue-eyed (see, for example, Zajal 137:11,4). Let it be noted that, throughout the Mediterranean area, according to folk beliefs, redheaded or blond people were, and still are, considered unlucky and untrustworthy; in particular, they are believed to cast the evil eye, especially if their eyes are blue (see Westermarck, E.A., Ritual and Belief in Morocco, London, 1926, 1, 419-421). The following passage from the medieval Spanish translation of the anonymous Arabic Sirr al-Asrār, attributed to Aristotle, reads like a perfect description of Ibn Quzmān's literary persona: “Onde sabet que el que es muy aluo et muy ruuio, et demas zarco, es sennal de desuergonçado, et de traydor, et de fornicioso et de poco seso. Et podedes esto entender en los çiclaues [siqlab = 'Slav', a term used in Andalus to designate slaves imported from Northern Europe], que son de tal facion que todos son locos, et traydores et deuergonçados. Pues guardat uos de cada uno ruuio et zarco, et si ouiere con esto la fruente mucho ancha, et la baruiella pequenna, et las mexiellas grandes, et el cuerpo roxo, et cabellos muchos en la cabeça, guardat uos del commo uos guardariedes de la biuora mortal". Translation: "Whereby you should know, concerning anyone who is very tall, and very blond, and blue-eyed to boot, that this indicates that he is shameless; a traitor, a fornicator, and a man of little sense. You can observe this in the Slavs, who are so built that the entire lot of them are crazy, treacherous, and shameless. Therefore, beware of every blond and blue-eyed person and, if he also has a very broad forehead, a small chin, large cheeks, a red body, and much hair on his head, beware of him as you would beware of a deadly viper". See Kasten, Ll.A. (ed.), Poridat de las poridades, Madrid, 1957, 62. For more on the "Slavs" in Andalus, see Monroe, J.T., The Shu 'ūbiyya in al-Andalus: The Risāla of Ibn García and Five Refutations, Berkeley, Los Angeles and London, 1970; Larsson, G., Ibn Garcia's Shu 'übiyya Letter: Ethnic and Theological Tensions in Medieval al-Andalus, Leiden and Boston, 2003. Regarding popular Hispanic prejudices against blonds and redheads, see such Castilian proverbs, as: "Ni gato ni perro de aquella color" ("Not even a cat or a dog should be of that color'); "Zurdos y calvos y rubios no habían de estar en el mundo" ('Left-handed, bald, and blond people should not be in this world'), (Bergua, J., Refranero español, Madrid, 1936, 487), as well as the Catalan proverbs "Amb roig de mal pèl, ni al cel" ("With an inauspicious-haired redhead [do not go] even if it is to heaven'), and "Home roig, de la fornada de Judes" ('A redheaded man is an associate [lit. 'from the baking'] of Judas'), (Cinc mil refranys catalans $i$ frases fetes, populars: Recull folkloric, Barcelona, 1985, 164). There are, in the Arab world, very ancient precedents for the prejudice against blond people (see Lewis, B., Race and Color in Islam, New York, 1970), who are, naturally, ethnic non-Arabs and, therefore, outsiders. Furthermore, the Devil is often described as being redheaded, while, in the illuminated MSS of the maquamas of al-Harīiñ, the trickster al-Sarūjī is often depicted as a redhead. Thus, blond or red hair, and blue eyes, are features that, according to the medieval science of physiognomy (Arabic firāsa), denote foolishness and treachery. For more on the evil eye, see Elworthy, F.Th., The Evil Eye: An Account of This Ancient and Widespread Superstition, New York, 1958; Maloney, C. (ed.), The Evil Eye, New York, 1976; Di Stasi, L., Mal Occhio [evil eye]: The Underside of Vision, San Francisco, 1981; Dundes, A. (ed.), The Evil Eye: A Folklore Casebook, New York, 1981. If, on the one hand, blondness is an indication of treachery and deceit, on the other, it is also a sign of aristocratic birth or standing. Ibn Hazm (383/994-456/1064) informs us that the Andalusi Umayyads were all blond (see Ibn Hazm, Ṭawq al-Hamāma, M.M. 'Abd al-Lațīf (ed.),

Al-Qantara XXXII 2, julio-diciembre 2011, pp. 307-332 ISSN 0211-3589 
Cairo, 1975, 31-32). This is confirmed by the poet Ibn Zaydūn who, in his poem known as the "Nūniyya", describes his beloved, the Umayyad princess Wallāda as having blond hair: "It is as if [God] had fashioned [her] of silver unalloyed, and had crowned [her] with a crown of gleaming native gold [hair] in uniqueness of creation and embellishment of beauty" (see Monroe, J.T., Hispano-Arabic Poetry: A Student Anthology, Berkeley, Los Angeles and London, 1974, 178-187, at 182-183, 1. 25). In contrast to the above, the peasantry is traditionally depicted as swarthy, dark-haired, and black-eyed, as may be seen in the numerous Spanish villancicos about morenas ('brunettes'), and corresponding Colloquial Andalusī-Arabic kharjas about samras (CA samrā', 'brunette'). Among the many Spanish villancicos about brunettes, see, for example, the following: Aunque soi morena / blanca io nascí / guardando el ganado / la color perdí. Translation: Although I am a brunette / I was born white: / Guarding the flock / I lost my complexion. (Frenk, M., Nuevo corpus de la antigua lírica popular hispánica (siglos XV a XVII), México D.F., 2003, 1, n. ${ }^{\circ} 139,132-133$ ). On the Arabic equivalent, the samra, see the following two Colloquial Andalusī-Arabic kharjas: samra kam dhā ș-ṣudūdi / bi-l-ḥurma yā sitti jūdī / samra fī wasți wādī / thamm salabti-nī fu'ādī. Translation: Brunette, how often have you shunned me! / By the respect you owe me, mistress, be generous! / Brunette, in the middle of a river valley, / There, you stole my heart. (Monroe, J.T., "Studies on the 'Harğas': The Arabic and the Romance 'Harğas", Viator: Medieval and Renaissance Studies, 8 (1977), 95-125, 113-114). Bi-l-lāh 'alay-ki yā samra / yā sitti yā zayn al-'ashīr / alwā bi-qalbī 'ināqa-k / fa-qum bi-nā 'ilā s-sarīr. Translation: I conjure you by God, $\mathrm{O}$ brunette, / $\mathrm{O}$ mistress, $\mathrm{O}$ ornament of the tribe, / Your embraces have stolen my heart, / So let us go to bed! (Monroe, "Studies on the "Harğas", 114). According to medieval Arabic treatises on physiognomy a small head was a sign of intelligence, whereas a large one was a sign of stupidity. For example, in his Kitäb al-'Iqd al-Farìd, the Andalusī author Ibn 'Abd Rabbihi (246/860-328/940) includes a long passage on the secretarial art and the merits of royal secretaries. In the process of describing the ideal secretary, he writes: "He should not be broad-framed, disproportionate, long-bearded, or large-headed, for it is claimed that wisdom and prudence do not adhere to an individual endowed with these defects" (Ibn "Abd Rabbihi, Kitāb al- 'Iqd al-Farīd, Cairo, 1949$1965,4,171-172$ ). In the context of the two portraits embedded in the $L B A$, in the first of which the ideal lady is portrayed as blond-haired and small-headed (s. 432), and in the second of which the Archpriest is portrayed as black-haired and big-headed (s. 1485), it might seem, at first glance, that blond hair and a fair complexion are being used to denote aristocratic breeding, whereas black hair and swarthiness are indications of peasant stock. The gap-teeth, broad hips, and long neck here assigned to the lady were, furthermore, considered signs of great beauty in medieval Arabic love poetry. One might thus assume that the lady is being portrayed as a delicate, aristocratic, intelligent, and beautiful individual, whereas the Archpriest is being presented as a foolish, coarse, and low-class bumpkin. Nevertheless, and given the popular belief that blond people were untrustworthy, and that the opposite was true of swarthy individuals, there are strong grounds to assume that, on a deeper level, the portraits are deliberately ambivalent: While the lady may well be aristocratic, beautiful, and intelligent, Juan Ruiz seems to be warning us that we should never trust fair ladies just because they are fair but, instead, always be wary of them until further signs of their reliability become apparent. In contrast, he seems to be saying that his own low-class, ugly, and foolish appearance may well mask an underlying trustworthiness. As always, the narrative voice is, in this instance, teaching us to delve more deeply into the meaning of things, and never to judge matters by their surface appearance alone.

Al-Qanțara XXXII 2, julio-diciembre 2011, pp. 307-332 ISSN 0211-3589 
making no headway in seducing the Archpriest, Don Amor indignantly departs from the scene, and is replaced by Doña Venus (ss. 576652), who acts on the god's behalf (i. e. she functions as his go-between), and finally succeeds in persuading the Archpriest to embark upon a career of promiscuity. In other words, the goddess thus successfully completes the seduction of the Archpriest. The above passages correspond to those in which, for Doña Garoça's benefit, Trotaconventos paints a verbal portrait of the Archpriest, who is depicted as a large-headed brunet, and whose love the procuress is pressuring the nun to accept (F'), (ss. 1485-1488). The Archpriest, who has previously rejected Don Amor (ss. 389d, 406d, 422d), now changes his tune, and invites the god to stay with him in his house (s. 1261), (E'). This thematic unit is followed by a long passage contained between ss. 1321 and 1507, in which the Archpriest, now a convinced, if merely would-be seducer, sends his elderly go-between Trotaconventos, on his behalf, to seduce the nun Doña Garoça (D'). Once again, and after the fashion embodied in works such as the Book of Kalila wa-Dimna, the virtuous nun and the scheming go-between trade stories designed to convince the opponent of either that the arguments of the other are sound. Eventually Trotaconventos succeeds in convincing the nun to succumb to the Archpriest's advances. The nun falls in love with the Archpriest, only to die two months later, thereby confirming both that the go-between's efforts were all in vain, and that the things of this world are themselves nothing but vanity.

The tale of Don Melón and Doña Endrina ('sloe') is told between ss. 653 and 891. In it Don Melón first attempts to, and then succeeds in, seducing Doña Endrina, through the good graces of the old crone Trotaconventos. After the seduction, Doña Endrina laments the loss of her virtue, but matters are soon righted when Don Melón "marries" her. This exemplum, in which the lead characters belong to the vegetal world (they are both fruit), is one ending in harmony, insofar as the two protagonists "marry" and, presumably, live happily ever after in a state either of marital union or of sexual conjunction. ${ }^{104}$ Once

${ }^{104}$ In his edition of the $L B A$, Corominas explains that the term casados, used in s. 891a means 'living together in sin; without benefit of clergy'. According to such an interpretation Don Melón and Doña Endrina would not have entered into a legal marriage contract, but would have agreed to live together. While this may well be so, it is worthy of note that in Alfonso X el Sabio's Las siete partidas (el libro del fuero de las leyes), the 
the Archpriest has told his tale, he launches forth into his career of attempted seductions, all of which end in failure, while simultaneously remaining oblivious to the fact that the exemplum he tells is inapplicable to his own situation since, as a member of the clergy, he cannot legally marry (note that here, as is so often the case in the Book of Kalīla wa-Dimna, a framed story with a moral ending is ironically subverted by its context). This passage corresponds thematically to that contained between ss. 1067 and 1314; it tells of the battle between Don Carnal and Doña Cuaresma ('Lent'); of how he is first defeated by, but later turns the tables on her, so that she is forced to flee from the city, and departs in holy pilgrimage. During Don Carnal's ensuing triumphal entry into that city, he is accompanied by his partner, accomplice, and fellow sinner, Don Amor. This episode, in which the lead characters, namely Don Carnal and Doña Cuaresma, represent the animal world (be it meat or fish), is one in which there is perpetual strife and disharmony between them, insofar as the two protagonists will alternate in prevailing over one another, in battle, on a yearly basis, to the end of time. They are, therefore, in a state of perpetual, incompatible, and inimical disjunction ( $\left.\mathrm{G}^{\prime}\right)$.

Between ss. 950 and 1042, we find a passage in which the Archpriest describes four misadventures he has had with four monstrous mountain women who, in effect, rape the unwilling and helpless Archpriest. Each episode is narrated twice: First in the mono-rhymed quatrains known as cuaderna via, and then in the form of a strophic song, sometimes a zajal. This grotesque "Passion of the Archpriest" corresponds to the more sublime "Passion of Jesus Christ" as it is narrated from ss. 1049 to 1066 . Let us designate these two sections $\mathrm{H}$ and $\mathrm{H}^{\prime}$ respectively. This leaves, in the very thematic center of the $L B A$, a prayer to the Virgin Mary contained between ss. 1043 and 1048 , which we shall designate as section I. If we now attempt to organize the above thematic sections of the $L B A$ into a table, it becomes clear that that work (as it has been reconstructed by modern editors) reveals an underlying structure based upon a form of ring

term casamiento is unequivocally used to designate legal marriage. (See "Partida Cuarta: de los desposorios e de los casamientos", 605-682). Similarly, in Martín Pérez, Libro de las confesiones, the word casar and its derivatives all imply, and are synonymous with, legal matrimony (See 73, 225, 659, 663, 664, 711). Either way, Don Melón and Doña Endrina would be in a permanent state of togetherness, in contrast to Don Carnal and Doña Cuaresma who are forever parting from one another, on a yearly basis. 
composition that is, if not absolutely perfect, at least arresting enough to elicit some form of commentary. Furthermore, since none of its modern editors seem to have been aware of the otherwise strikingly chiastic nature of the $L B A$ 's structure, this encourages one to think that their labors in restoring the text are more than plausible. The following is a chart summarizing that structure: ${ }^{105}$

105 The thematic units in which ring composition is clearly present, according to this proposed reading, are highlighted in bold script and assigned the letters A B C [...] C' B' A'. Those in which no ring composition has been detected are not. For a somewhat different interpretation of ring composition in the $L B A$, see Meyers, O.T., "Symmetry of Form in the LBA", Philological Quarterly, 51 (1972), 74-84. For ring composition as a universally used literary technique, see the bibliography listed by Niles, J.D., "Ring Composition and the Structure of Beowulf", PMLA, 94 (1979), 924-935. The validity of this critical approach to reading literary texts was discussed by Peterson, R.G., "Critical Calculation: Measure and Symmetry in Literature", PMLA, 91 (1976), 367-375. For a recent and most welcome study, see Douglas, M., Thinking in Circles: An Essay on Ring Composition, New Haven and London, 2007. That distinguished anthropologist states: "Ring composition is found all over the world, not just in a few places stemming from the Middle East, so it is a worldwide method of writing. It is a construction of parallelisms that must open a theme, develop it, and round it off by bringing the conclusion back to the beginning. It sounds simple, but, paradoxically, ring composition is extremely difficult for Westerners to recognize. To me this is mysterious. Apparently, when Western scholars perceive the texts to be muddled and class the authors as simpletons, it is because they do not recognize the unfamiliar method of construction" (Douglas, Thinking in Circles, X). For individual Quzmānī zajals previously analyzed by me, in which ring composition has been identified and used as a tool of interpretation, see (1) Monroe, "Prolegomena to the Study of Ibn Quzmān" (see note 49), 78-128 (on Zajal 12); (2) Monroe, "Prolegómenos al estudio de Ibn Quzmān" (see note 55), (on Zajal 137); (3) Monroe, "Wanton Poets and Would-be Paleographers" (see note 31); (4) Monroe, J.T., "Salmà, el toro abigarrado, la doncella medrosa, Ka'b al-Aḥbār y el conocimiento del árabe de don Juan Manuel: Prolegómenos al Zéjel Núm. 148 de Ibn Quzmān", Nueva Revista de Filología Hispánica, 36 (1988), 853-878; (5) Monroe, J.T., "The Underside of Arabic Panegyric: Ibn Quzmān's (Unfinished?) Zajal No. 84", Al-Qantara, 17 (1996), 79-115; (6) Monroe, J.T., "The Striptease That Was Blamed on Abū Bakr's Naughty Son: Was Father Being Shamed, or Was the Poet Having Fun? (Ibn Quzmān's Zajal No. 133)", in J.W. Wright Jr. and E.K. Rowson (eds.), Homoeroticism in Classical Arabic Literature, New York, 1997, 94-139; (7) Monroe and Pettigrew, "The Decline of Courtly Patronage" (see note 48), (on Zajal 90); (8) Monroe, "Improvised Invective" (see note 48); (9) Monroe, "The Mystery of the Missing Mantle" (see note 48); (10) Monroe, J.T., "Ibn Quzmān's 'Zajal 118': An Andalusī 'Ode to the Onion"”, in Á. Sáenz-Badillos, L. Girón Negrón and M. Gaylord (eds.), Proceedings: "Los quilates de su Oriente": La pluralidad de culturas en la Península Ibérica durante la Edad Media y en los albores de la Modernidad: A Conference in Honor of Francisco Márquez Villanueva (held at Harvard University, January 17, 2002), (in press); (11) Monroe, "Literary Hybridization in the Zajal" (see note 50); (12) Monroe, J.T., "Andalusi-Arabic Strophic Poetry as an Example of Literary Hybridization: Ibn Quzmān's 'Zajal 147' (The Poet's Reluctant Repentance)", in K. Reichl (ed.), Medieval Oral Literature, de Gruyter Lexikon, Berlin and New York [in press]; (13) Monroe, "Faithful Watchdogs" (see note 56), (on Zajals

Al-Qantara XXXII 2, julio-diciembre 2011, pp. 307-332 ISSN 0211-3589 


\begin{tabular}{|c|c|c|}
\hline & \multirow[t]{2}{*}{$1-10$} & Prayer to God. \\
\hline & & Prologue in Prose by the Author, Juan Ruiz, Archpriest of Hita. \\
\hline & $11-19$ & Prayer to God. \\
\hline $\mathbf{A}$ & $20-43$ & JOYS OF THE VIRGIN MARY. \\
\hline $\mathbf{B}$ & $\begin{array}{l}44-63 \\
64-70\end{array}$ & $\begin{array}{l}\text { Debate between the Greeks and Romans (On misunderstan- } \\
\text { ding signs). } \\
\text { Instructions to the reader on how to understand the Book. }\end{array}$ \\
\hline & $71-114$ & $\begin{array}{l}\text { Men and other animals, by nature, desire female company } \\
\text { (Doctrine of Latin Averroists). }\end{array}$ \\
\hline $\mathbf{C}$ & 115-122 & $\begin{array}{l}\text { Misadventure with Ferrand García (Clever young man steals } \\
\text { the lady from the Archpriest-García [fox] the conejero [dog/ } \\
\text { ferret] gets the conejo [rabbit/vulva]). }\end{array}$ \\
\hline & $123-180$ & $\begin{array}{l}\text { The planets (i. e. nature) control men's lives, but God controls } \\
\text { the planets (Refutation of Latin Averroists). }\end{array}$ \\
\hline $\mathbf{D}$ & 181-652 & $\begin{array}{l}\text { Debate of Don Amor and, on his behalf, Doña Venus, with the } \\
\text { Archpriest (Seduction). Seven Deadly Sins Invoked (ss. 217-320). }\end{array}$ \\
\hline $\mathbf{E}$ & $372-422$ & The Archpriest rejects Don Amor ("leave my house"). \\
\hline $\mathbf{F}$ & 431-435 & $\begin{array}{l}\text { Don Amor describes the ideal woman: Small head, blonde hair, } \\
\text { broad hips, eyebrows well apart, small ears, long neck, gap- } \\
\text { toothed. }\end{array}$ \\
\hline $\mathbf{G}$ & 653-891 & $\begin{array}{l}\text { Marriage of Don Melón and Doña Endrina (Fruit, harmony, } \\
\text { conjunction). }\end{array}$ \\
\hline & $892-949$ & $\begin{array}{l}\text { Various adventures with ladies; recitation of the names of the } \\
\text { go-between. }\end{array}$ \\
\hline $\mathbf{H}$ & 950-1042 & $\begin{array}{l}\text { Rape of the Archpriest by the Mountain Women (His } \\
\text { "Passion"; Cruz = 'Crotch' - His 'Crotch-ifixion' - } \\
\text { 'Stations of the Crotch'). }\end{array}$ \\
\hline I & 1043-1048 & PRAYER TO THE VIRGIN MARY. \\
\hline
\end{tabular}

21, 92, and 147); (14) Monroe, J.T., "Form and Content in Ibn Quzmān's 'Zajal 59' and '138', in which 'Matla' and Harja are Twofold in Function', Boletin de Literatura Oral, 1 (2011), 14-39. See too, Hernández, G.E., "El arte satírico de Ibn Quzmān: Zéjel núm. 20", Actas del Congreso Romancero-Cancionero, E. Rodríguez Cepeda (ed.), Madrid, 1991, 2, 383-408; Farrin, R.K., "Season's Greetings: Two 'I $\bar{d}$ Poems by Ibn Quzmān", JAL, vol. 35 (2004), pp. 247-269 (on Zajals 8 and 48). For further bibliography on the Andalusī zajal, see Heijkoop, H. and Zwartjes O., Muwashshah, Zajal, Kharja: Bibliography of Strophic Poetry and Music from al-Andalus and their Influence in East and West, Leiden and Boston, 2004. See especially, the groundbreaking study by Raymond K. Farrin, demonstrating that ring composition also applies to the Classical Arabic poetic tradition (Farrin, R.K., Abundance from the Desert: Classical Arabic Poetry, Syracuse, NY, [2011]). 


\begin{tabular}{|c|c|c|}
\hline $\mathbf{H}^{\prime}$ & $1049-1066$ & $\begin{array}{l}\text { The Passion of Christ (Cruz }=\text { 'Cross' }- \text { His Crucifixion - } \\
\text { 'Stations of the Cross'). }\end{array}$ \\
\hline $\mathbf{G}^{\prime}$ & $1067-1314$ & $\begin{array}{l}\text { Battle of Don Carnal and Doña Cuaresma (Flesh, dishar- } \\
\text { mony, disjunction) }\end{array}$ \\
\hline $\mathbf{e}^{\prime}$ & 1225-1314 & The Archpriest welcomes Don Amor ("be my guest"). \\
\hline $\mathbf{D}^{\prime}$ & 1321-1507 & $\begin{array}{l}\text { Debate of Trotaconventos, on behalf of the Archpriest, with } \\
\text { Doña Garoça (Seduction). }\end{array}$ \\
\hline \multirow[t]{2}{*}{ f' } & $1485-1488$ & $\begin{array}{l}\text { Trotaconventos describes the Archpriest: Large head, black } \\
\text { hair, broad shoulders, eyebrows well apart, long nose, big } \\
\text { mouth, thick lips. }\end{array}$ \\
\hline & $1508-1617$ & $\begin{array}{l}\text { Moorish woman, Arabic music, death of Trotaconventos. Seven } \\
\text { Deadly Sins Invoked (ss. 1583-1605). }\end{array}$ \\
\hline $\mathrm{C}^{\prime}$ & $1618-1625$ & $\begin{array}{l}\text { Misadventure with Don Furón (Foolish young man loses the } \\
\text { lady for the Archpriest - Furón [ferret] the conejero [ferret] } \\
\text { fails to get the conejo [rabbit/vulva]). }\end{array}$ \\
\hline $\mathbf{B}^{\prime}$ & $1626-1634$ & Instructions to the reader on how to understand the Book. \\
\hline \multirow[t]{5}{*}{ A } & 1635-1649 & JOYS OF THE VIRGIN MARY. \\
\hline & $1650-1660$ & How scholars beg in the name of God. \\
\hline & $1661-1689$ & $\begin{array}{l}\text { "Ave Maria". Praise of the Virgin Mary. } \\
\text { Colophon in Prose by the Copyist Alfonso Paradinas. }\end{array}$ \\
\hline & $1690-1709$ & $\begin{array}{l}\text { Cardinal Gil de Albornoz, Archbishop of Toledo from } 1337 \text { to } \\
\text { 1350, orders the clerics of Talavera to give up their mistresses. } \\
\text { The resulting consternation among those clerics. }\end{array}$ \\
\hline & $1710-1728$ & Blind beggars' songs. \\
\hline
\end{tabular}

The misadventure with Ferrand García, previously mentioned, begins with a zajal in which the story is first told lyrically (ss. 115120), followed by two stanzas in cuaderna via (ss. 121-122) in which further details are provided, this time in narrative form. In s. 116, which constitutes the first strophe of the zajal, the poet states:

Cruz cruzada, panadera, tome por entendedera, tome senda por carrera como [haz el] andaluz.
Cross, wearing a crusader's cross, the baker-woman, I took as my beloved;

I mistook a pathway for a highway

As does the Andalusī Moor.

In Old Spanish, the word cruz not only meant 'cross', but also 'crotch'. ${ }^{106}$ As far as the word cruzada is concerned, it not only meant

${ }^{106}$ Márquez Villanueva, "Spanish Cazurro Poetry”, 97; Zahareas, "Troba Cazurra”.

Al-Qanțara XXXII 2, julio-diciembre 2011, pp. 307-332 ISSN 0211-3589 
'wearing a cross' and, hence, 'a crusader', but also 'one to whom the sign of the cross had been made', i. e. 'blessed', as well as 'crossed' in a general sense. ${ }^{107}$ Furthermore, the term pan 'bread' also bore an obscene connotation, namely 'female pudenda', as a result of which its derivative, panadera, not only meant 'a woman who baked and/ or sold bread,' but also 'a woman who sold her pudenda', i. e. 'a whore'. ${ }^{108}$ Given the ambiguity of these three words, various meanings may be assigned to s. $116 \mathrm{a}$, as follows:

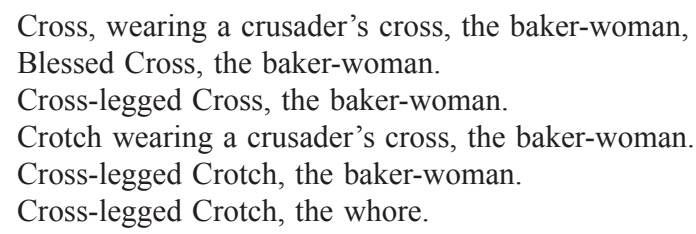

Hence, by means of a complicated, multileveled amphibology, the meaning of the line can descend from the sublime to the ridiculous; from the religious to the profane; from the pure to the obscene. We are thus left with one literal meaning that is sexually explicit (crotch: Ibn Rushd's rhetorical interpretation), and a second, deeper, and religious meaning (cross: Ibn Rushd's theological interpretation). Pursuing this line of thought, we might venture to conclude rationally (Ibn Rushd's philosophical interpretation), that the cross is not always, or entirely, incompatible with the crotch, since both concepts are expressed by means of the same word cruz, and that, as a consequence, there is not always an absolute conflict between religion and sex. Once again, we have grounds to suspect that we may be dealing with the problem of ecclesiastical celibacy.

107 Diccionario de la lengua española, Madrid, RAE, 2001, 1, 690-691, s.v. 'Cruzar'; Corominas and Pascual, Diccionario crítico etimológico, 2, 253-254, s.v. 'Cruz'; Cuervo, R.J., Diccionario de construcción y régimen de la lengua castellana, Santafé de Bogotá, 1994, 599-602, s.v. 'Cruzar'.

${ }^{108}$ Márquez Villanueva, F., "Pan 'pudendum muliebris' y los españoles en Flandes”, Hispanic Studies in Honor of Joseph H. Silverman, J.S. Ricapito (ed.), Newark, Delaware, 1988, 247-269. In Martín Pérez, Libro de las confesiones (p. 471), bakerwomen are further stereotyped as being dishonest merchants, insofar as they undercook the bread they bake, in order to make it weigh more that it should, and thereby charge a higher price for it. In addition, they are deceitful, thievish, and impious; they use foul language, behave in a generally lewd and scandalous way, and are addicted to gluttony and excessive winebibbing. According to such a portrayal, they are, therefore, "no better than they should be". 
Armed with the knowledge that the word carrera, as it is being used in this stanza, not only designates, on the literal level, a highway intended for vehicular traffic, but also implies, on the allegorical level, a path toward salvation (see n. 93, above), we are led to a conclusion parallel to the one previously outlined, namely, that the text is simultaneously suggesting (A) that the poet/persona has followed the wrong worldly path (or adopted the wrong 'method'), ${ }^{109}$ in his attempt to seduce Crotch, the whore, whereas (B) like an Andalusī, he has followed the wrong spiritual path in his attempt to win eternal salvation by means of the blessed, bread-dispensing Cross (in which bread, of course, represents the body of Christ).

If we examine the chiastic structure of the $L B A$, as outlined in the previous chart, we find our suspicions amply confirmed: The very center of the work, thematically speaking (I), consists of a prayer to the Virgin Mary. After that prayer is concluded, the story of the passion of Christ is told (H'), including the Stations of the Cross and the crucifixion. Always keeping in mind that the word cruz means both 'cross' and 'crotch', the corresponding thematic section that immediately precedes the prayer to the Virgin Mary, namely section $(\mathrm{H})$, begins to acquire a deeper and more interesting meaning: It is the tale of how the hapless Archpriest is raped by four monstrous mountain women. In this context, it becomes the tale of his human "passion", including his own "stations of the crotch" and his "crotch-ifixion". Just as in s.116a we find three words in which a sexual meaning coincides with a religious one, here we find a sexual episode $(\mathrm{H})$ corresponding to a religious one $\left(\mathrm{H}^{\prime}\right)$, while both are presided over by the central, bridging, and intercessory figure of the Virgin Mary (I), thereby suggesting, once again, that the cross and the crotch are not always, or necessarily, incompatible. Insofar as the amphibology found in the early misadventure with Cruz leads us to precisely the same conclusion as does the very thematic center of the entire work, we might venture to suggest that the $L B A$, far from being an anthology of poems haphazardly put together, as Corominas was misled by Hatzfeld into believing, is a carefully structured work, and that, insofar as minute details in the work are reflected within its larger structural patterns, it also exhibits considerable organic unity, as do

${ }^{109}$ In the etymological sense of the word, derived from Greek met'-hodós, in which the element hodós literally means 'road'.

Al-Qanțara XXXII 2, julio-diciembre 2011, pp. 307-332 ISSN 0211-3589 
all great literary masterpieces. Furthermore, and insofar as the work is episodic in structure and picaresque in theme, it exhibits a remarkable similarity to the Arabic maqāma and zajal genres, while the ironic tales told within the central tale itself, bear a strong resemblance to those found in the Oriental genre of the frametale. We are thus justified in arguing that the structure of the $L B A$ is greatly indebted to Eastern genres, whereas its materials are largely Western. In this respect, it is a hybrid work. It is true, of course, that the specific combination of elements borrowed from Eastern genres, and that constitutes the supporting structure of the $L B A$, which I hope to have identified and pointed out, does not occur, to the best of my knowledge, in any specific Arabic literary work per se. Nevertheless, we are dealing here with a masterpiece of Spanish literature and, as is always the case, literary masterpieces are far more than the sum of their components or the product of their sources.

\section{Concluding Remarks: A Topsy-Turvy World of Fools?}

Earlier in this exposition, it was pointed out that mudéjar churches were hybrid monuments, the structure of which was provided by the imported, dominant, Ibero-Romance culture, whereas their materials were borrowed from the local, dominated Arabic civilization. Likewise, it was indicated that precisely the opposite occurs in the case of architectural monuments such as the Mosque of Córdoba, whose structure is essentially that of a mosque, whereas many of the elements out of which it is built are borrowed from non-Islamic civilizations. Let me briefly end by suggesting, in light of the examination to which I have subjected the $L B A$ that, in this respect, and just as is the case with the Quzmānī zajal, the work of Juan Ruiz is also a hybrid work. In what way are the $L B A$ and the Quzmānī zajal related to one another?

From a comparative perspective, the structure of the $L B A$ is Arabic and Islamic. By this, I mean that its structure, as first argued by Francisco Fernández y González and María Rosa Lida de Malkiel, is a derivative of the Arabic maqāma genre, to which I would add that this structure has been modified by the technique of inserting "framed" tales within its various picaresque episodes. This technique was, in turn, borrowed from Oriental works such as the Book of Kalīla wa- 
Dimna, which was translated directly from Arabic into Spanish in AD 1251 of the Julian calendar, at the command of the future king Alfonso X, the Learned. ${ }^{110}$ The original Arabic maqāma genre has been further modified by an inversion of perspective, after the fashion of the Quzmānī zajal: In the Classical maqāma a victim narrates how he was successfully deceived by a trickster, whereas in the $L B A$, a would-be trickster narrates how he was unsuccessful in his attempts at deceiving a potential victim, exactly as occurs, all too often, in the Quzmāni zajal. The structure of the $L B A$ is, therefore, in itself, a hybrid of the maqāma, the frametale, and the zajal genres, the first two of which came to the Iberian Peninsula from the Arab East, whereas the third, namely the zajal was adopted from the local, Ibero-Romance tradition, and developed, on Andalusī soil, by Arab poets. In contrast, the $L B A$ 's materials are largely Graeco-Latin, Romance, and Christian. This is so, in the sense that the work recounts the numerous attempts, made by a Christian Archpriest, to seduce various and sundry women, all of whom (with the exception of two nuns, who are as desperate for sex as he is) reject his advances. The work further includes characters adopted from Classical Antiquity, such as the Pagan divinities Doña Venus and Don Amor. As in the case of the Quzmānī zajal, sex is, therefore, one of the major, obsessive concerns of the $L B A$.

Ultimately, the $L B A$ is subversive, insofar as it attempts to criticize the rule of priestly celibacy that had been imposed upon the Western Christian clergy by the Roman Church only a century before the $L B A$ was written. Years ago, the $L B A$ was characterized by Américo Castro, as being a mudéjar work. ${ }^{111}$ To his keenly perceptive suggestion,

110 Döhla, H.-J. (ed.), El Libro de Calila e Dimna: nueva edición y estudio de los dos manuscritos castellanos, Saragossa, 2009. Among other translations of Arabic frametale collections into Old Spanish, see: Keller, J. Esten (ed.), El libro de los engaños, Valencia, 1959. For a few adaptations of the frametale genre into European languages,

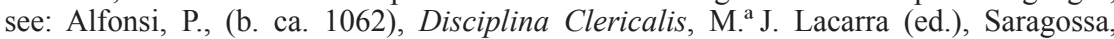
1980; Juan Manuel, Infante de Castilla, El conde Lucanor, F.A. Fernández and J. Alonso Iglesias (eds.), Madrid, 2009; Boccaccio, G., Il Decamerone, Milano, 1954; Chaucer, G., Canterbury Tales, A.C. Cawley (ed.), London, Melbourne and Toronto, 1978; Navarre, M. de, L'heptaméron, Paris, 1964. The frametale genre has continued to echo on down to the present with: Allende, I., Eva Luna, Barcelona, 1987, and Allende, I., Cuentos de Eva Luna, Barcelona, 1989.

${ }^{111}$ Castro, A., The Structure of Spanish History, E.L. King (transl.) Princeton, 1954, chap. 12, "The Archpriest of Hita and his 'Libro de Buen Amor'", 392-465 and, specifically, p. 403. 
we may now add the following nuance: In both the $L B A$ and the Quzmāni zajal, the literary structure is borrowed from the dominated culture (the structure of the Spanish $L B A$ is Arabic and Eastern, whereas that of the Arabic zajal is Romance and Western), in contrast to which, the literary materials used in both works are largely borrowed from the dominant culture (the Arabic zajal's materials are Arabic, insofar as they are borrowed from the qașida and the maqāma, whereas those of the Spanish $L B A$ are Graeco-Latin and Romance). This feature appears to coincide with the fact that both these works are subversive, insofar as they both offer a critique of certain social norms and customs prevalent in the two authors' respective societies: Ibn Quzmān views the piety of the dominant Almoravid religious leaders as hypocritical and, consequently, hollow, whereas Juan Ruiz views the Western Christian rule of priestly celibacy as unnatural and, therefore, unenforceable. It should be further pointed out that, if these two literary examples are any indication of the validity of a rule with wider implications, we might venture to suggest that, when a hybrid work is subversive, it tends to abandon the literary norms that are usually expected of the formal, high culture and to adopt, in their stead, literary strategies borrowed from the popular rank and file (the Quzmānī zajal is couched in Colloquial Arabic diction even though Ibn Quzmān was a learned poet conversant with Classical Arabic [the prologue to his Diwwān is composed in the Classical register of the language], at the same time that Juan Ruiz, who obviously read Latin, and was a man of some learning, conceals his true nature behind the persona of a popular minstrel; he writes in Castilian, rather than Latin, and he goes out of his way to stress his lack of wisdom and knowledge). ${ }^{112}$ Both authors, in sum, hide their considerable formal education behind the assumed persona of an ignorant fool, as a strategy allowing them to criticize society after the manner of the ritual clown.

In light of the above, let us note that literary works such as the Quzmānī zajal and the $L B A$ are parallel to one another, insofar as their structure derives from a foreign, dominated culture, whereas their materials derive from a native, dominant culture. Therefore, the $L B A$ is not a straightforward or normal mudéjar work, as Américo

112 See specifically, $L B A$, ss. 152, 1133, 1574, and 1633, for the Archpriest's protestations of ignorance and lack of expertise in various fields of knowledge. 
Castro brilliantly postulated, but rather, it might more accurately be described as an inverted mudéjar work. In a similar, but parallel fashion, the Quzmānī zajal represents an inversion of those principles of hybridization that characterize the Mosque of Córdoba, insofar as its materials are Arabic and, therefore, dominant, whereas its structure is Romance and, therefore, dominated. Both the $L B A$ and the Quzmānī zajal are, from this perspective, structurally equivalent, if culturally opposite, expressions of that extraordinary, multicultural society that was medieval Iberia. Finally, let me suggest that, when a literary work is subversive, that is to say, when it is critical of certain social practices prevalent in the dominant culture, its author may prefer to adopt a literary structure borrowed from the often oppressed social stratum of the underdog, as a convenient, psychological vantage point from which to lash out with impunity at abuse and corruption in the high places of his own dominant culture. In so doing, the author is deliberately adopting the Bakhtinian critical perspective of what Claudio Guillén, in his masterly study of Spanish picaresque literature, brilliantly identified as the societal "half-outsider". ${ }^{113}$

Recibido: 29/09/2009

Aceptado: 12/02/2010

${ }^{113}$ Bakhtin, M.M., Rabelais and his World, Cambridge, Mass., 1968. On the concept of the "half-outsider" in Spanish picaresque literature, see, Guillén, C., Literature as System: Essays Toward the Theory of Literary History, Princeton, 1971, 80. 